\title{
POLE2 wt Allele
}

National Cancer Institute

\section{Source}

National Cancer Institute. POLE2 wt Allele. NCI Thesaurus. Code C132124.

Human POLE2 wild-type allele is located in the vicinity of $14 q 21.3$ and is approximately 45 $\mathrm{kb}$ in length. This allele, which encodes DNA polymerase epsilon subunit 2 protein, plays a role in DNA-dependent replication. 